\title{
OS SIGNOS DA FOTOGRAFIA: UM OLHAR SOBRE O PROJETO ÊXODOS DE SEBASTIÃO SALGADO
}

TALITA SAVARIS

UNIVERSIDADE DO OESTE DE SANTA CATARINA JOAÇABA, SANTA CATARINA, BRASIL E-MAIL: SAVARIS.THALITA@HOTMAIL.COM

SILVIA SPAGNOL SIMI DOS SANTOS UNIVERSIDADE DO OESTE DE SANTA CATARINA JOAÇABA, SANTA CATARINA, BRASIL E-MAIL: SILVIA.SIMI@UNOESC.EDU.BR

HTTP://DX.DOI.ORG/10.5902/2316882X21285 
OS SIGNOS DA FOTOGRAFIA: UM OLHAR SOBRE O PROJETO ÊXODOS DE SEBASTIÃO SALGADO

Resumo: O presente estudo semiótico tem por objetivo analisar os signos inseridos em cinco fotografias do projeto "Êxodos" de Sebastião Salgado, que retrata movimentos migratórios do mundo todo. É possível identificar, por meio das obras, elementos sígnicos do contexto social, político e econômico que apresentam-se de forma clara nas imagens e que retratam a condição humana em forma de signos de denúncia.

Palavras-chave: fotografia; Semiótica; Sebastião Salgado; Movimentos migratórios.

LOS SIGNOS DE FOTOGRAFÍA: UNA VES EN EL PROYECTO ÊXODOS DEL SEBASTIÃO SALGADO

Resumen: El presente estudio semiótico tiene por objetivo analizar los signos insertados en cinco fotografías del proyecto "Éxodos" de Sebastião Salgado, que retrata movimientos migratorios de todo el mundo. Es posible identificar, por medio de las obras, elementos sígnicos del contexto social, político y económico que se presentan de forma clara en las imágenes y que retratan la condición humana en forma de signos de denuncia. Palabras clave: Fotografía;. Semiótica; Sebastião Salgado; Los movimientos migratorios.

THE SIGNS OF PHOTOGRAPHY: A LOOK ON THE ÊXODOS PROJECT OF SEBASTIÃO SALGADO

Abstract: The present semiotic study aims to analyze the signs inserted in five photographs of the project "Exodus" by Sebastião Salgado, which depicts migratory movements from all over the world. It is possible to identify, through the works, signic elements of the social, political and economic context that are clearly presented in the images and that portray the human condition in the form of signs of denunciation.

Keywords: Photography; Semiotics; Sebastião Salgado; Migratory movements. 


\section{INTRODUÇÃO}

O interesse em pesquisar esse assunto é direcionado pela curiosidade em estudar e entender o seguinte ponto: como a semiótica pode auxiliar na compreensão da imagem na mente do receptor.

O procedimento utilizado para a coleta de dados foi a pesquisa bibliográfica, que é desenvolvida com base em material já elaborado, constituído por livros e artigos científicos. Como se trata de um estudo sobre tema específico e de grande valor representativo, será adotado o método de procedimento monográfico, caracterizado por teorias já consolidadas e textos produzidos por vários autores, para analisar e fundamentar a semiótica e o estudo dos símbolos.

A pesquisa em questão é descritiva, tendo como objetivo proporcionar mais familiaridade com o problema e torná-lo mais explícito. Quanto aos processos técnicos, foi realizada uma análise qualitativa, sendo o projeto "Êxodos" de Sebastião Salgado, o objeto de estudo.

Sebastião Salgado é um dos maiores exemplos de fotografia documentarista, que voltou o seu olhar para as causas humanitárias. Sua obra conhecida como "Êxodos” teve caráter de denúncia da condição humana, mostrando-se uma grande estratégia de reflexão, valorizando assim a fotografia como agente de conscientização. O fotógrafo teve por objetivo provocar uma reflexão sobre questões relacionadas à política, economia e condição social.

Com toda sua técnica e histórias vividas, Salgado conseguiu criar um estilo único, é internacionalmente conhecido e já recebeu inúmeros prêmios pelo mundo, como reconhecimento do seu trabalho. Com sua linguagem peculiar, esse artista conquista os olhares de todos, olhares de admiração e de curiosidade.

Na comunicação, a fotografia tem um papel importante e está constantemente inserida nas áreas de Jornalismo e Publicidade e Propaganda. A fotografia é muito mais que uma simples técnica ou um simples equipamento, trata-se de uma legítima forma de comunicação. Por isso, a importância em analisar e identificar os seus elementos e suas significações, para compreender como a linguagem fotográfica específica consegue produzir efeitos e valores em quem recebe a mensagem. A intenção da pesquisa é obter um estudo alicerçado sobre as fotografias do projeto "Êxodos" de Sebastião Salgado e suas significações.

Rev.Cad. Comun. Santa Maria, v.21, n.1, art 7, p.149 de 171, jan/abr.2017 
A composição teórica e a metodologia deste trabalho encontram-se na segunda e na terceira seção, onde consta também a teoria semiótica, desde o conceito de signo até as dez classes dos signos e tricotomias. Para a abordagem, são utilizadas as obras dos seguintes autores: Santaella (1996, 1999, 2004, 2007), Nöth (1999, 2004, 2008), Peruzzolo (2004) e Peirce (2008). Enquanto a análise teórica, para identificar os elementos semióticos presentes nas fotografias, segue na quarta seção. Ao final, a conclusão aponta as considerações finais e os resultados, por meio desta pesquisa.

\section{SURGIMENTO E EVOLUÇÃO DA FOTOGRAFIA}

Antes mesmo de iniciar e aprofundar os estudos sobre as técnicas fotográficas é de suma importância estudar a origem da fotografia e a sua história. Quem explica essa origem é o autor Folts (2007) ao afirmar que o inventor francês Joseph Nicéphore Niépce em 1826 produziu a primeira imagem reconhecida. Com uma placa de estanho coberta com derivado de petróleo chamado de betume, a imagem foi produzida e demorou cerca de oito horas de exposição à luz solar.

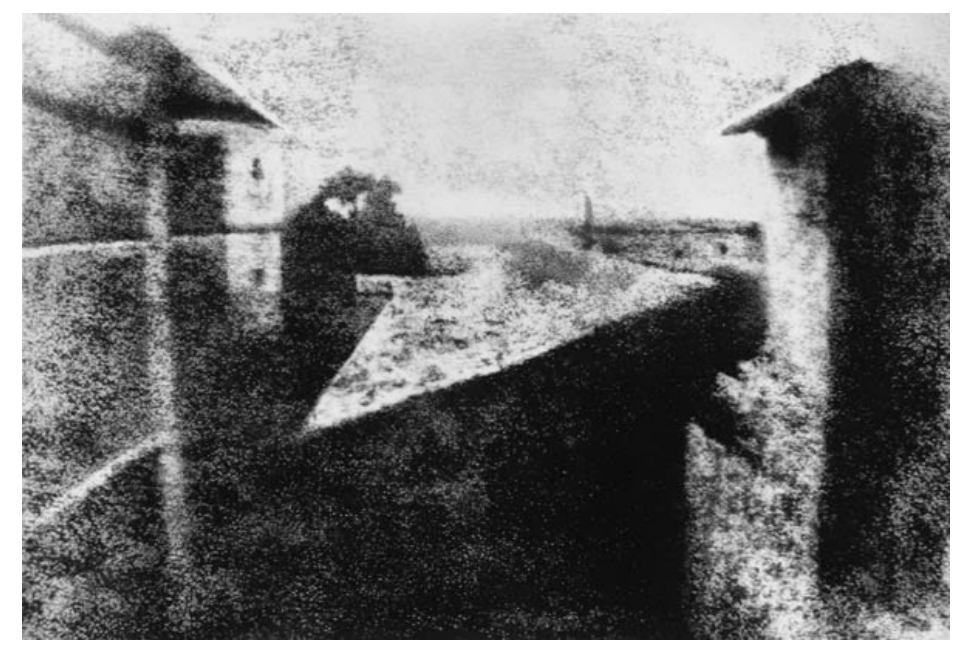

Figura 1 - Primeira fotografia

Fonte: Joseph Nicéphore Niépce (1826).

Ainda de acordo com Folts (2007), a fotografia nasceu em preto e branco, especificamente o preto sobre o branco. Estas fotografias ganham destaque pela riqueza de suas tonalidades, onde se costuma utilizar a luz e a sombra de forma acentuada para criar efeitos estéticos. Ainda hoje, muitos profissionais fotografam apenas em preto e branco. Como é o caso de um dos maiores fotógrafos brasileiro, Sebastião Salgado.

Rev.Cad. Comun. Santa Maria, v.21, n.1, art 7, p.150 de 171, jan/abr.2017 


\subsection{FOTOGRAFIA P\&B}

A fotografia em preto e branco é uma técnica muito popular, que envolve nostalgias e decorre das memórias de fotografias antigas, como também do início da televisão. De acordo com Chichito et al. (2006), Leonardo da Vinci, no século XV, já havia pensado na arquitetura de uma câmera escura - sala sem luz onde se revelam os milagres da fotografia -, mas só em julho de 1827, com Nicéphore Niépce que se conseguiu tirar a primeira foto propriamente dita. Ao usar material que se tornava rígido em contato com a claridade, a imagem aparecia somente depois de oito horas de exposição.

Segundo Fontes (1995), a estrutura dos filmes pode ser dividida em três elementos básicos: o suporte flexível ou base, a gelatina onde estão suspensos os microcristais ou haletos de prata e os próprios sais sensíveis à luz. A diferenciação de cada tipo de filme passa por sutilezas no processo de fabricação. A espessura e os componentes adicionados à gelatina, a forma, o tamanho, a quantidade vão determinar muitas características importantes, entre elas a sensibilidade o contraste e a definição. Para os fotógrafos, o interesse está no resultado final, explica Fontes (1995, p. 13):

Entendendo os mecanismos internos pelos quais os diversos filmes passam, podemos definir critérios de escolha e processamento para atingir determinados resultados. Com essa intenção faz-se necessário dividir o estudo dos filmes em duas etapas: propriedades físicas e estruturais e propriedades fotográficas.

Segundo Fontes (1995), todas as qualidades e características finais do negativo dependem da revelação e exposição do filme, pois esses fatores determinam a interpretação fotográfica da luz e da cena fotografada.

Podemos dizer desta forma que a fotografia é sempre uma imagem de algo que está atrelada ao referente e que atesta a existência do histórico que a própria fotografia gerou. Analisar uma fotografia implica reconstituir no tempo um assunto, por isso a semiótica é a escolhida para sustentar a análise neste trabalho. Para Santaella (2005, p. 303), a fotografia:

É uma imagem documento, fruto da aderência seguida do afastamento de um agente em luta entre a visibilidade do real. Nela o fragmento é capturado pela máquina por meio de um sujeito. Sombra, resto, corte, nesse tipo de imagem o índice reina soberano.

Rev.Cad. Comun. Santa Maria, v.21, n.1, art 7, p.151 de 171, jan/abr.2017 
Ainda de acordo com Santaella (1997, p. 37) "[...] são máquinas de registro que não apenas fixa, num suporte reprodutor, aquilo que os olhos vêm e os ouvidos escutam, mas também amplificam a capacidade humana de ouvir e ver", diante disso, instaurando novos prismas que sem apareIhos o mundo não teria. A percepção é de fundamental importância para os fotógrafos, os detalhes são importantes - luz, sombra, textura, enquadramento. É a totalidade complexa destes elementos se relacionando, que se cria o significado de cada imagem. Por isso, nas próximas linhas será abordado o conceito de signo, significado, significante e assuntos relacionados à semiótica e fotografia.

\section{SEMIÓTICA: A TEORIA GERAL DOS SIGNOS}

Antes mesmo de iniciar e aprofundar os estudos sobre as facetas da semiótica é necessário compreender sua origem e do que trata essa teoria. Quem explica claramente os conceitos da semiótica é a autora Santaella (1986, p. 7), ao afirmar que "semiótica vem da raiz grega semeion, que quer dizer signo." A mais importante corrente semiótica conhecida e estudada, é a semiótica peirceana, que tem como fundador Charles Sanders Peirce (1839-1941), filósofo e matemático norte-americano que, ao criar essa teoria, possibilitou sua aplicação em diversas áreas do conhecimento, como a Filosofia, a Sociologia e a Comunicação.

A semiótica nos permite categorizar sons, imagens, palavras em todas as suas manifestações. Santaella (2008, p. 59) afirma que semiótica "é a teoria de todos os tipos de signos, sinais, códigos e linguagens." Portanto, conceitualmente, a semiótica é a ciência geral de todas as linguagens. Uma teoria pela qual é possível analisar e interpretar todos os signos presentes em todos os tipos de linguagem.

Assim, a teoria semiótica de Peirce é baseada na noção de signo, que significa "uma coisa que representa outra coisa para alguém" (PEREZ, 2004, p. 141). O signo só pode ser considerado signo quando tem o poder de substituir ou representar algo diferente dele, ou seja, o seu objeto.

\subsection{OS TRÊS PONTOS DE VISTA SEMIÓTICOS}

Para Santaella (2002), quando aplicada ao design ou à publicidade, a análise semiótica tem por objetivo tornar explícito o potencial comunicativo que a imagem ou peça apresenta, quer dizer: explorar através da análi-

Rev.Cad. Comun. Santa Maria, v.21, n.1, art 7, p.152 de 171, jan/abr.2017 
se, quais são os efeitos que um dado produto está apto a produzir em um receptor. Estes efeitos podem ser de várias ordens, desde o nível de uma primeira impressão até o nível de um julgamento de valor que o receptor pode, muitas vezes, ser levado a efetuar.

A semiótica, fundamentada nos ideais de Santaella (2002), baseada nas ideias de Peirce, indica três pontos de vista fundamentais: o ponto de vista qualitativo-icônico, o singular-indicativo e o convencional-simbólico.

Santaella (2002, p. 70) define o ponto de vista qualitativo icônico, como sendo "[...] os aspectos responsáveis pela primeira impressão que o produto provoca no receptor, é a impressão que brota da primeira olhada, transformando-se em uma associação de ideias. Tais associações são produzidas por relações de comparação por semelhança, chamadas de icônicas."

De acordo com Santaella (2002, p. 70), o ponto de vista convencional-simbólico apresenta os padrões de design, e o que este design atende. Examina os valores do produto, marca, mercado consumidor, origem, funções a que se destina, e qual usuário visa entender.

Ainda conforme Santaella (2002, p. 70), o ponto de vista singular indicativo analisa os traços de identidade do produto, como: qualidade, cor, uso, tamanho e manipulação. Observa também a relação do produto com a sua origem, consumidor, funções e qualidades.

Portanto, a semiótica possibilita compreender e estudar os diversos tipos de linguagem. Os estudos de Peirce sobre a teoria dos signos desempenham um papel primordial na compreensão de diversos assuntos ligados ao campo da comunicação, sendo um deles a fotografia.

\section{PROCEDIMENTOS METOdOLÓGICOS}

Torna-se importante identificar e analisar os elementos semióticos e suas significações na fotografia para compreender como eles são utilizados para produzir efeitos e valores em quem recebe a mensagem. Com base no quadro teórico e nos três pontos de vista semióticos de Santaella (2002) e também na classificação sígnica de Peirce (2008), será feita uma análise do projeto fotográfico "Êxodos", de Sebastião Salgado.

Foram escolhidas cinco fotografias, sendo elas as que apresentavam expressões mais marcantes, que representavam simbolicamente o ambiente em que a imagem foi captada. Busca-se na análise um modo de

Rev.Cad. Comun. Santa Maria, v.21, n.1, art 7, p.153 de 171, jan/abr.2017 
compreender, por meio da sua obra, elementos semióticos e aspectos gerais sobre o contexto das fotografias. Cada foto tem elementos muito marcantes sejam eles objetos, movimentos ou até mesmo olhares que dão todo o sentido para cada uma delas. Todas as fotografias escolhidas retratam o movimento migratório vivido no final do século XX em todo o mundo por mais de 40 países, sendo um deles o Brasil.

A intenção desta pesquisa foi obter um estudo alicerçado nos elementos semióticos, ou seja, na utilização de signos em cinco fotografias do projeto. Desta forma, foi realizado um estudo das mesmas e dos elementos semióticos contidos nelas, por meio da decupagem de cada fotografia.

Ao serem analisados e classificados, os signos podem ser interpretados e a partir desta interpretação é possível entender como foram utilizados nas fotografias, a fim de produzir algum efeito no interpretante. Também é possível entender a relação do signo, seu objeto e sua significação.

\subsection{O PROJETO ÊXODOS}

Para Salgado (1999), este projeto conta a história da humanidade em trânsito. Traz uma narrativa perturbadora, pois são poucas as pessoas que abandonam a sua terra natal por vontade própria. Em geral são elas migrantes, refugiados, ou exiladas constrangidas por forças que não tem como controlar, estão fugindo da pobreza, da repressão ou das guerras. Muitas vezes partem com os pertences que conseguem carregar, viajam sozinhas, com as famílias ou em grandes grupos.

Durante seis anos Sebastião Salgado passou por quarenta países, trabalhando em meio a fugitivos, nas estradas ou em campos de refugiados, ou ainda em favelas urbanas onde eles frequentemente iam parar. Conforme Salgado (2000), muitos desses atravessavam os piores momentos das suas vidas, estavam assustados, humilhados, mas mesmo assim aceitavam ser fotografados.

A experiência operou uma profunda mudança em mim. Ao dar início a este projeto, eu estava habituado a trabalhar em condições difíceis. Pensava que minhas convicções políticas ofereciam respostas para um grande número de problemas. Acredita sinceramente que a humanidade avançava num rumo positivo. Estava despreparado para o que veio a seguir. As coisas que aprendi acerca da natureza humana e do mundo em que vivemos deixaram-me profundamente apreensivo quanto ao futuro. (SALGADO, 1999, p. 7).

Rev.Cad. Comun. Santa Maria, v.21, n.1, art 7, p.154 de 171, jan/abr.2017 
É provável que a ideia deste projeto esteja ligada as mudanças que Sebastião enfrentou ao longo da vida. Segundo Santana (2013), Sebastião Salgado nascido em uma fazenda em Minas Gerais, aos cinco anos de idade mudou-se para uma cidadezinha chamada Aimorés e na sua adolescência morou em Vitória. No Espírito Santo começou a cursar Economia. Tempo depois encontrou sua esposa Lélia e foram morar em São Paulo. Cada uma dessas mudanças o levou para um universo urbano mais denso. Em 1969, com o país sob regime militar, Sebastião e sua família mudaram-se para Europa onde ele começou a se deparar com refugiados, parte imigrantes, parte estudantes.

A partir destas experiências, Sebastião começou a identificar-se com os exilados, imigrantes, com pessoas que estavam inventando uma nova maneira de viver, longe dos lugares onde nasceram. Outra inspiração para o projeto êxodos surgiu de projetos anteriores, das viagens por ele feitas pela América Latina, África e países da Ásia. (SALGADO, 2000, p. 7).

No livro Da minha terra à terra, Sebastião Salgado explica um pouco mais sobre a construção deste projeto, onde ele conheceu muitos lugares, começando pelo Brasil. E em toda parte ele constatou, com muita tristeza a degradação das condições da vida. De acordo com Salgado (2013), visitou megalópoles e favelas, cidades asiáticas tentaculares como Xangai, Jacarta e Bombaim, cidades onde novos migrantes estavam chegando em busca de trabalho.

Salgado (2013, p. 7) descreve "Vi ilhas de riqueza num oceano de pobreza. Nunca esquecerei de Manila e seus clubes de golfe privados, enquanto as ruas pululavam de crianças paupérrimas, Lembro também de todos os vietnamitas que faziam filas por horas a fio à porta do consulado Americano em busca de um visto."

No fim, a história que eu pensava conhecer na ponta dos dedos deixou-me profundamente abalado e confuso em minha sensibilidade e em minhas convicções. Eu já havia testemunhado tantas tragédias ao longo de diferentes reportagens que me pensava imune a elas. Mas não estava preparado para encontrar tanta violência, tanto ódio e tanta brutalidade. Pensava que a Europa não conheceria novas limpezas étnicas; não imaginava o pesadelo dos Bálcãs. Os massacres e o genocídio que presenciei na África chegaram a tal grau de atrocidade que me deixaram doente. Profundamente apreensivo quanto ao futuro da humanidade. (SALGADO, 2013, p. 51).

Rev.Cad. Comun. Santa Maria, v.21, n.1, art 7, p.155 de 171, jan/abr.2017 
O projeto de Sebastião Salgado é cheio de significações, ao longo de suas viagens o artista busca trazer a "humanidade", mostrar o ser humano, como vivem, o que fazem. Diante disto, a partir de agora serão apresentadas as fotografias escolhidas para a análise de acordo com os três pontos de vistas semióticos elaborados por Santaella.

\section{ANÁLISE SEMIÓTICA}

A primeira fotografia escolhida para análise é "Os ícones da vitória" (Imagem 1). De acordo com Sontag (2004), a foto foi feita no Brasil, entre 1980 e 1996, para o autor a imagem apresenta uma visão critica da realidade dos trabalhados rurais. Sontag (2004) explica que a foto é formada por integrantes do Movimento dos Trabalhadores Rurais Sem Terra (MST).

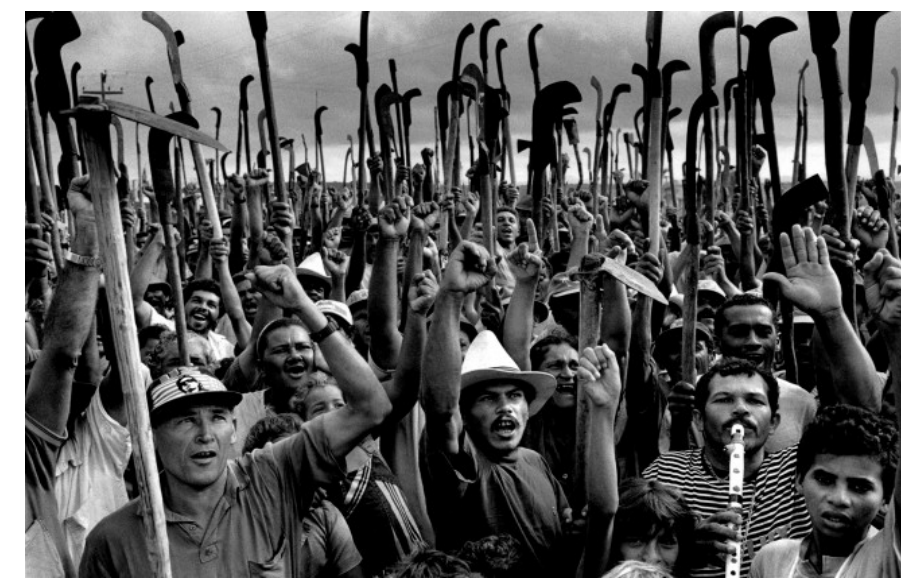

Fotografia 7 - Imagem 1: Os ícones da vitória

Fonte: Salgado (2000).

Um grande acampamento com 2800 famílias foi formado na entrada da Fazenda Cuiabá no Sertão do Xingó, às margens do Rio São Francisco. Durante vários meses essa gente viveu penosamente na esperança do decreto de desapropriação, que foi, afinal adotado no dia 6 de maio de 1996. Manifestação dos camponeses em comemoração ao que consideram uma vitória, mas que, na realidade, foi só um ato de justiça. (SALGADO, 1997 p. 143).

Segundo Sobrinho (2014), praticamente a massa humana toma dois terços da imagem indo do primeiro plano que está contido no primeiro terço ao último dos terços onde pouco acima está a linha do horizonte. O movimento e a vida da fotografia são dados pelas ações gestuais e as expressões faciais que consolidam a celebração de uma vitória, pois, se-

Rev.Cad. Comun. Santa Maria, v.21, n.1, art 7, p.156 de 171, jan/abr.2017 
gundo Adorno (2011) isto ocorre pelo fato de:

\begin{abstract}
Não há que opor ao belo formal uma natureza material: o principio deve compreender-se como produto de devir, na sua dinâmica, e, deste modo, conteudalmente. A imagem do belo, enquanto imagem do uno e do diverso, surge com a emancipação da angústia perante a totalidade esmagadora e a opacidade da natureza. (ADORNO, 2011. p. 85).
\end{abstract}

Conforme Santaella (2005), para explorar o potencial comunicativo, de um produto, peça ou imagem impressa, a semiótica propõe três pontos de vista para explicar o efeito que podem produzir em um receptor.

Do ponto de vista qualitativo icônico, é possível identificar nesta fotografia os primeiros signos que prendem a atenção: as foices, as enxadas e a flauta na mão de uma das pessoas retratas, todos ícones. As ações gestuais, os instrumentos de trabalho e as expressões faciais, podem estar representando várias emoções como uma celebração vitoriosa, uma reivindicação, um pedido, ou exigência dos trabalhadores, para Peirce, qualidades, ou seja, qualissignos.

Pela fotografia estar em preto e branco também a percebemos como quali-signo, pois é uma qualidade sígnica imediata, é a primeira impressão. Onde, de alguma forma, o artista procura passar as emoções destas pessoas. A ausência de cor faz com que seja possível prestar atenção nos ricos detalhes da fotografia. A iluminação utilizada é a natural, o que deixa a fotografia com um aspecto mais brando sem muitas sombras e torna possível ver o rosto de cada pessoa, de cada expressão, alegria, tristeza, cansaço ou euforia, todos qualissignos.

No ponto de vista singular indicativo, nota-se que a composição da imagem tem como objetivo alcançar um efeito emocional, passar um clima e quebrar a monotonia. Nota-se que os elementos estão organizados e enquadrados devidamente, com isto, classifica-se a composição da imagem em dicente, pois só é possível interpretar todos os elementos, a composição em geral, porque o signo está existindo como tal, sendo real. Portanto, tem-se a comprovação de um fato, a imagem existe e está organizada da forma que está.

Ainda sobre a iluminação, na secundidade, tem-se um índice quando analisadas as expressões das faces, pois é o índice que proporciona um resultado de singularização, formada pela relação do preto e branco e

Rev.Cad. Comun. Santa Maria, v.21, n.1, art 7, p.157 de 171, jan/abr.2017 
resultado de singularização, formada pela relação do preto e branco e da iluminação.

Ao observar os detalhes dos instrumentos ocorre um fato, um evento participar, que remete a um signo. Diante disto, já se tem um sin-signo, compreendido, neste caso, como uma celebração vitoriosa, uma reivindicação, um pedido, ou exigência dos trabalhadores, ainda sem muitos outros entendimentos.

De acordo com Santaella (1986), esta interpretação faz parte do ponto de vista singular indicativo, ou seja, é o que oferece a experiência da ação e reação. Observa-se, desta forma, que dois deles seguram em suas mãos duas enxadas e o outro um instrumento musical, aparentemente uma flauta e na sua outra mão, parece fazer um sinal. Santaella (1986) acrescenta que o singular indicativo é falar em pensamento, no entanto, é falar em processo de mediação interpretativa entre o observador da fotografia e os fenômenos. É sair, portanto, do segundo como aquilo que impulsiona para o universo do terceiro.

Já no ponto de vista do convencional simbólico, percebe-se que o sinal que o homem faz, o simples sinal é um índice, pois está na secundidade, é existente. $O$ signo se refere a um acontecimento, algo que a mulher está pedindo. Neste caso compreende-se que a mulher parece pedir calma, este sinal de calma é um dicente, ou seja, é uma interpretação do observador, uma existência real, e diante disso, envolve também um rema. Os demais personagens da foto com as mãos fechadas aparentam o sentido de força, garra e busca pela luta de suas terras, com isto classifica-se como um índice, pois é um fato que tem relação direta com o que está acontecendo na foto. Os elementos, a composição, o agrupamento de coisas permitem compreender a busca pela luta de suas terras.

Santaella (1986) explica que é ponto de vista do convencional simbólico que aproxima um primeiro e um segundo em uma síntese intelectual, e que corresponde à camada de inteligibilidade, ou pensamento em signos, através do qual representa e interpreta o mundo.

No meio da foto observa-se a mão de uma mulher, que não está em primeiro plano. Com uma visão mais articulada percebe-se que ela está com a mão fechada e com seu dedo indicador apontando para o céu. Esta indicação para o céu enquadra-se na segunda classe dos signos definida por Peirce (2008) como o sin-signo icônico remático, onde algo ou em evento existe e suas qualidades levam à ideia de objeto. Por ser semelhan-

Rev.Cad. Comun. Santa Maria, v.21, n.1, art 7, p.158 de 171, jan/abr.2017 
te ao objeto que representa é um ícone e é interpretado através de um rema. Ou seja, o dedo indicador aponta alguma coisa, refere-se a alguma coisa e pode ser interpretado como um signo.

A obra também aponta para um contexto capitalista, onde se mostra as relações entre os sem terra, a sociedade e os latifúndios, em evidência está a terra como meio de sobrevivência humana. Este contexto manifesta claramente a visão do artista Sebastião Salgado em favor dos menos favorecidos, em busca de uma sociedade mais igualitária e justa. $\mathrm{O}$ artista busca uma reflexão sobre os problemas sociais como: fome, injustiça, guerra, exploração no trabalho e más condições de sobrevivência. Compreende-se, pois, um legi-signo, onde a cor representa a tristeza e a composição da foto explica os detalhes do acontecimento. O legi-signo, não pode existir sem os sin-signos prévios, por isso, após toda a compreensão da foto, chega-se ao entendimento de fome, injustiça e guerra.

A segunda obra escolhida é "Os Dinkas do Sul do Sudão" (Imagem 2). O povo Dinka é um grupo étnico que habita a região da bacia do Nilo e em outras partes do Sudão. Para Fleury (2013): Eles contam com a criação de gado em campos durante a estação seca e com o crescimento de milhetos em acampamentos fixos durante a estação chuvosa. São considerados a maior tribo étnica no sul do Sudão, é um povo que vive debaixo do sol, por isso, possuem um tom de pele notavelmente escuro. Alguns exploradores chegaram a considerá-los como sendo a população mais escura da África. Eles cobrem seus corpos e rostos com cinzas, para se protegerem da malária e de insetos perigosos e também porque enxergam as cinzas como uma beleza natural. Quando as cinzas são removidas de seus corpos é possível notar a característica extremamente negra de suas peles.

Conforme Fleury (2013). Os dinkas vivem em perfeita harmonia com seus animais, os quais consideram possuírem ligação direta com Deus. "Crianças vivem ao redor do gado usufruindo do alimento proporcionado por eles e sua companhia. Notavelmente o gado tem um papel central na vida deles, muitas vezes, ao longo do ano, eles se alojam com seus gados em acampamentos nos quais podem somar milhares de bois". 


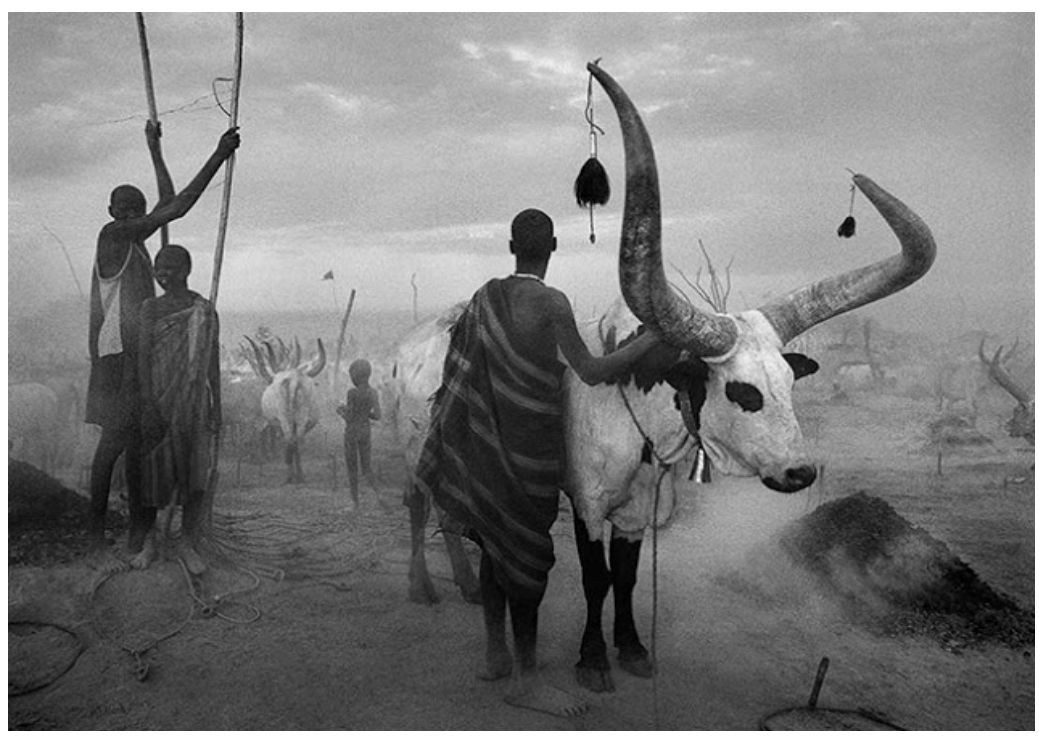

Fotografia 8 - Imagem 2: Os Dinkas do Sul do Sudão Fonte: Salgado (2000).

Do ponto de vista qualitativo icônico, além da tonalidade em preto e branco da foto, que está na primeiridade, é possível identificar nesta fotografia o primeiro signo que prende a atenção: os chifres com os enfeites na ponta, que são considerados ícones. As ações gestuais, os instrumentos de trabalho e as expressões faciais, podem estar representando várias emoções como esperança, força, garra que para Peirce são qualidades, ou seja, qualissignos.

A cor que se nota primeiro é o branco do animal, o branco no caso desta imagem, é um quali-signo, pois é visto primeiro e somente depois que os detalhes das formas e outros elementos são percebidos.

No segundo ponto de vista, destacamos que a iluminação utilizada é a natural, uma luz muito suave já que aparentemente o tempo está nublado, diante disto é um índice, pois o tempo nublado está representando e deixando a fotografia com belos nuances de cinza. É nítido o contraste existente entre as cores em tons de cinza até a cor branca dos bois. A ausência de cor faz com que se preste atenção nos ricos detalhes da fotografia.

Quando se observa atentamente a imagem, identificamos o animal e, desta forma, temos um sin-signo, pois o animal está ali e se manifesta por todos os elementos.

A composição da imagem apresenta elementos bagunçados e integra a classe dicente, pois é através da composição da imagem que se conse- 
gue ter todas as informações para o entendimento da imagem.

Já as cordas são índices de que algo passou pelo local, que algo aconteceu ou está acontecendo. Ainda para Santaella (1986) quando o índice é afetado pelo seu objeto passa a ter, obrigatoriamente, uma qualidade comum a esse objeto. Um índice envolve um ícone e torna-se índice a partir do contato efetivo com uma qualidade do seu objeto que o modifica e o torna um signo.

Observando o ponto de vista do convencional simbólico, percebe-se três homens magros e com poucas roupas, e uma criança, ao fundo, que está completamente nua. É possível deduzir que eles não enfrentam uma condição de vida muito fácil, além de perceber a pobreza existente, pelos corpos das pessoas.

Porém, o que é notório é o cuidado que eles têm com os animais, que aparentam estarem bem cuidados, apresentam um porte físico imponente. Um deles está segurando um animal, possivelmente estão indo para algum lugar ou esperando alguma coisa. E esse movimento de ir e vir, de migrar é exatamente o sentido de todo o projeto "Êxodos".

A terceira obra escolhida é "A luta pela terra: a marcha de uma coluna humana". De acordo com Sontag (2004) a obra retrata a marcha de 12 mil sem-terra, em uma noite de inverno no Paraná.

Salgado (2013) descreve a fotografia: Era impressionante a coluna dos sem-terra formada por mais de 12 mil pessoas, ou seja, 3 mil famílias, em marcha na noite fria daquele início de inverno no Paraná. 0 exército de camponeses avançava quase completo. Escutava-se apenas o arfar regular de peitos acostumados a grandes esforços e os ruídos que tocavam o asfalto. Pelo rumo que seguia a corrente, não era difícil imaginar que o destino final fosse a fazenda Giacometti, um dos imensos latifúndios tão típicos do Brasil. Marginalmente explorados, esses latifúndios, todavia, em razão das dimensões colossais garantem aos seus proprietários rendas milionárias. 


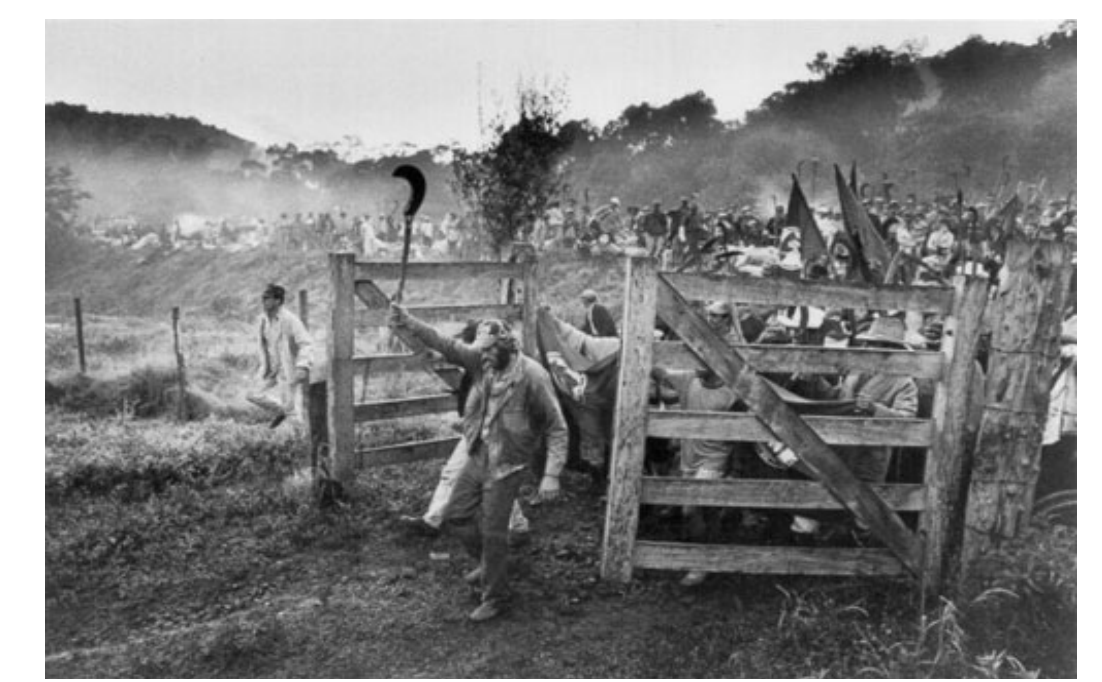

Fotografia 9 - Imagem 3: A luta pela terra: a marcha de uma coluna humana Fonte: Salgado (2000).

Do ponto de vista qualitativo-icônico, na Imagem 3 o primeiro signo que chama a atenção é a foice na mão do homem abrindo a porteira, a foice é considerada um ícone. Por ser uma foto na cor preto e branca, a sua cor se classifica como um quali-signo. Primeiro observa-se o preto, que se envolve com o branco, e após este momento, percebe-se a iluminação que se apresenta em destaque, onde o natural da iluminação permite compreender o que está acontecendo pois é através da iluminação que se pode observar a multidão chegando.

No segundo ponto de vista, o singular indicativo, nota-se que também é uma foto preta e branca, novamente com iluminação natural. Pode-se deduzir através da luz mais clara e da posição desta luz na fotografia, que o sol estava na linha do horizonte, aliando este fator com a névoa baixa, sendo classificado como um índice, pois pode-se dizer que a foto foi realizada ainda no amanhecer. Sontag (2004) explica sobre o contexto histórico da foto, o exército de camponeses avançava quase completo. Escutava-se apenas o arfar regular de peitos acostumados a grandes esforços e os ruídos que tocavam o asfalto. Pelo rumo que seguia a corrente, não era difícil imaginar que o destino final fosse a fazenda Giacometti, um dos imensos latifúndios típicos do Brasil.

A composição da imagem apresenta detalhes importantes nesta imagem, é a composição que apresenta os fatos, como a grama, a terra, as foices, pois eles estão apontando para o entendimento da foto.

Do ponto de vista convencional simbólico, em quase todas as suas fotos o objeto central é a figura de um homem. Compreende-se, portanto,

Rev.Cad. Comun. Santa Maria, v.21, n.1, art 7, p.162 de 171, jan/abr.2017 
que o artista utiliza os homens como símbolos de força, símbolo da pessoa que está sempre à frente da luta, por isso, enquadra-se no ponto de vista convencional simbólico e também como um símbolo. Nöth (2008, p. 83) explica que "[...] o símbolo é o signo da segunda tricotomia que participa da categoria de terceiridade. Cada símbolo é, portanto, e ao mesmo tempo, um legi-signo". Na visão de Santaella (1986, p. 93-94):

O símbolo não é uma coisa singular, mas um tipo geral. E aquilo que ele representa também não é um individual, mas um geral. Assim são as palavras. Isto é: signos de lei e gerais[...] É evidente também que o símbolo, como lei geral, abstrata, para se manifestar precisa de réplicas, ocorrências singulares. Desse modo, cada palavra escrita ou falada é uma ocorrência através da qual a lei se manifesta. Daí que os símbolos sejam signos triádicos genuínos, pois produzirão como interpretante um outro tipo geral ou interpretante em si que, para ser interpretado, exigirá um outro signo, e assim ad infinitum. Símbolos crescem e se disseminam, mas eles trazem, embutidos em si caracteres icônicos e indiciais. (SANTAELLA, 1986, p. 93-94, grifo do autor).

Assim, um símbolo é tudo aquilo que representa alguma coisa por meio de uma associação de elementos. Outro elemento que chama atenção são as cordas. Compreende-se as ideias de representação, toda a ordem da imagem, onde a foto direciona para um Brasil, triste e miserável. Os signos apresentados, a princípio, proporcionam a ideia de um caos instalado no Paraná e nota-se que o artista se encontra distante da paisagem, como se não quisesse se aproximar daquela realidade.

A quarta obra analisada é conhecida como "As crianças". De acordo com Sontag (2004), a foto foi feita em 6 de abril de 1994 em Ruanda, logo após a morte do presidente Hutu do país, aparentemente causada por um míssil disparado contra seu avião. Os refugiados deste país foram para a região de Goma, no Zaire, atual República Democrática do Congo. A obra mostra três crianças do orfanato sós, onde abrigava 4 mil órfãos e seu número crescia diariamente. No campo de Kibumba, milhares de ruandeses morriam todos os dias, vítimas de uma das mais horríveis tragédias da história recente. A maioria deles tinha a esperança de que a fronteira fosse reaberta logo.

Rev.Cad. Comun. Santa Maria, v.21, n.1, art 7, p.163 de 171, jan/abr.2017 


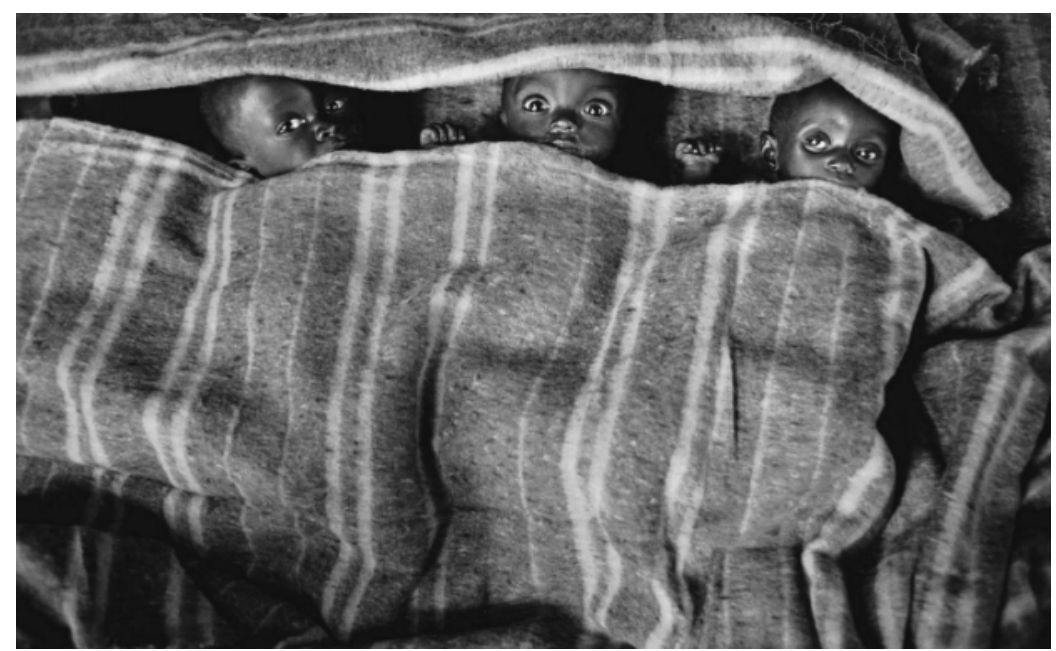

Fotografia 10 - Imagem 4: As crianças

Fonte: Salgado (2000).

A foto apresenta três crianças, do ponto de vista qualitativo-icônico, o primeiro signo que chama a atenção são os olhos das crianças que são considerados ícones. Novamente na primeiridade, nota-se que a fotografia é preta e branca. A iluminação utiliza é a natural, o que deixa a fotografia com texturas interessantes. Mesmo com iluminação natural pode-se notar nuances de luz e sombra em toda a foto, principalmente no rosto das crianças, deixando-os em evidência.

Em uma visão mais detalhada e classificada na secundidade, onde se tem uma reação, é possível perceber que duas das crianças estão com os olhos mais esbugalhados, já a outra está com um olhar cansado e diante disto temos um índice, ou seja, os olhos cansados, esbugalhados apontam para uma situação triste.

Outro signo bastante representativo na foto é o cobertor que provavelmente está os aquecendo, podemos assim classificar na segunda classe definida por Peirce, como sin-signo icônico remático, onde algo ou um evento existe e suas qualidades levam à ideia de objeto. Por ser semelhante ao objeto que representa é um ícone e é interpretado através de um rema, sobre um sin-signo icônico remático.

Do ponto de vista do convencional simbólico, o símbolo do medo é algo muito claro na obra. Na semiótica o símbolo é a lei geral que está na interpretação e também no próprio símbolo e, desta forma, produz um interpretante. O símbolo é interpretado como um signo por intermédio de uma lei que determinará este interpretante. O interpretante, por sua vez, formado pela associação de ideias feita na mente do intérprete, é o 
que promove a conexão entre o símbolo e o objeto. A obra não esconde a dor e a fome das crianças, símbolo de um país que acabou de sofrer muito.

Segundo Sebastião (2000), as duas crianças com os olhos mais aberto, que pareciam estar prestando atenção no que estava acontecendo, sobreviveram. Já a criança com os olhos cansados e tristes, infelizmente, não sobreviveu.

A quinta obra é conhecida como "Estação Church Gate", a foto foi tirada na Índia, em 1995. É uma foto, mais uma vez, em preto e branco, que aparenta mostrar o passado ou o presente, a segurança ou a aflição. As imagens do artista são possuidoras de muitos signos, muitos elementos, o que torna seu trabalho magnífico.

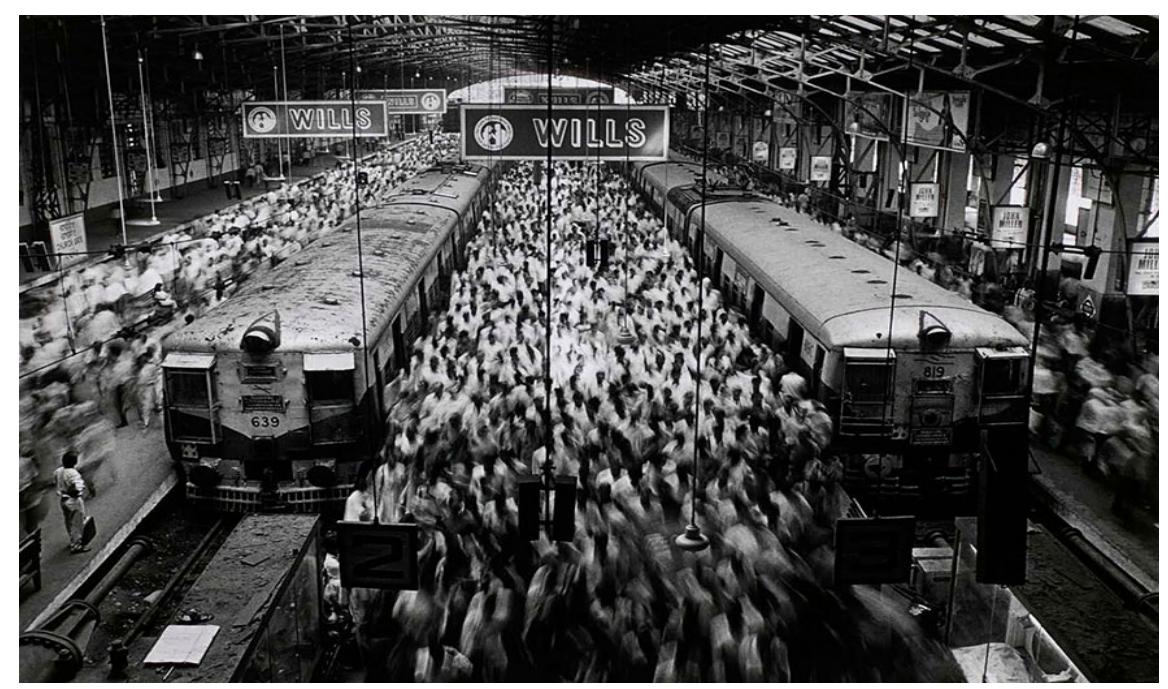

Fotografia 11 - Imagem 5: Estação Church Gate

Fonte: Salgado (2000).

Do ponto de vista qualitativo-icônico, o primeiro signo que chama a atenção é a multidão o aglomerado de pessoas que são considerados ícones.

No segundo ponto de vista, o singular indicativo, observamos dois vagões de trens e algumas placas de sinalização. Inicialmente, identifica-se o índice, pois estas pessoas estão partindo ou chegando de algum lugar, todas estão em movimento. O fato curioso é que as placas de sinalização não estão em movimentos e que existe uma pessoa no canto inferior esquerdo que não está em ritmo acelerado. A figura da mulher é nítida, diferente dos demais, mas não se tem o entendimento, o motivo disto. Desta forma, classifica-se a mulher como Sin-signo Indicativo Remático.

Rev.Cad. Comun. Santa Maria, v.21, n.1, art 7, p.165 de 171, jan/abr.2017 
Percebe-se que também se trata de uma foto preta e branca. A iluminação utilizada é também a natural, existe uma luz ultrapassando as janelas do lado lateral direito, que se classifica como um índice. Provavelmente o teto desta estação também deixa a luz do sol entrar, resultando em um local bem iluminado com poucas sombras. Observa-se que o fotógrafo utilizou uma velocidade de obturador mais lenta da câmera deixando, assim, o que estava em movimento borrado, o que proporciona a sensação de movimento, e o que estava parado ficou nítido na foto.

Do ponto de vista do convencional simbólico é notória a sensação de movimento, mudança e de agitação que esta fotografia transmite. A imagem indica que está ocorrendo uma mudança em um ritmo frenético. A composição da imagem é cheia de detalhes, são tantos elementos que permitem uma compreensão clara que ali é uma estação de trem, por isso temos um legi-signo.

Justamente na época desta fotografia o mundo estava passando por fortes mudanças econômicas, políticas e tecnológicas, e foi isto que Sebastião Salgado quis demonstrar. Desta forma, nota-se a agitação da cidade, do trabalho, do movimento das pessoas, e este entendimento o classifica na terceiridade.

Esta fotografia foi escolhida para finalizar a análise, justamente, por retratar o que o Sebastião Salgado propôs neste projeto, que é mostrar a humanidade em trânsito, em movimento.

Em cada viagem feita, ele buscou trazer símbolos, signos e representações desta mudança. Por este motivo o contexto social, político e econômico se apresentaram de forma clara, mostrando a realidade da sociedade.

Nas fotografias analisadas, é possível perceber a existência de uma única linguagem. $\mathrm{O}$ que as unem nesta linguagem, principalmente, é o fato de todas serem fotografias em preto e branco. Aliando isto com a utilização de luz natural presente em todas elas, pode-se concluir que o fotógrafo quis retratar exatamente o que ele estava vendo através das lentes de sua câmera sem modificar nada, não usou flashes, nem rebatedores, nada que pudesse mudar a atmosfera real da fotografia. Apesar de não seguirem uma única regra de enquadramento, conforme citado na seção II, visualmente todas as imagens analisadas são harmônicas.

Para melhor elucidação, será utilizado novamente o esquema da triangulação dos três polos do signo e suas relações.

Rev.Cad. Comun. Santa Maria, v.21, n.1, art 7, p.166 de 171, jan/abr.2017 


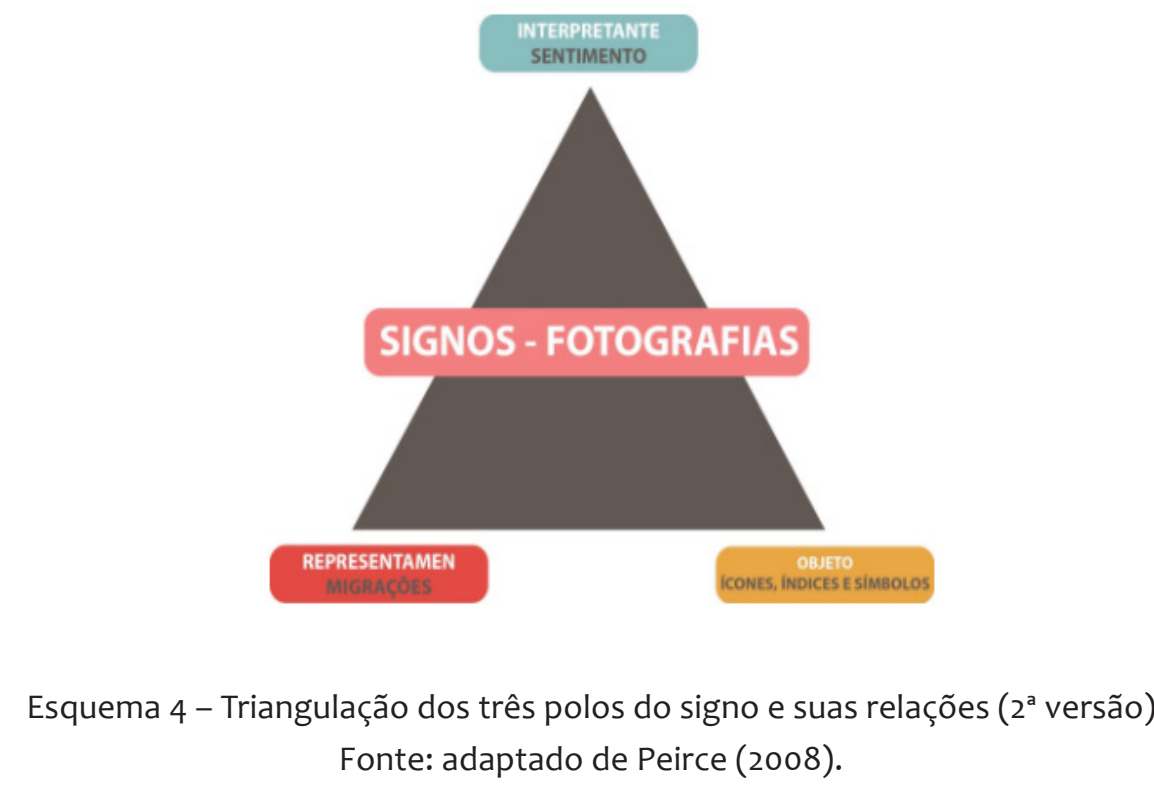

Em relação a tríade do signo, é composta por objeto, interpretante e representamen conseguimos identificar claramente a proposta das fotografias. No vértice objeto, percebe-se que os ícones, índices e símbolos existentes nas imagens que são responsáveis por retratar a realidade vivida em cada foto.

Já no vértice representamen é constata-se que o movimento migratório retratado nas fotos, movimento este que no final do século XX foi bastante significativo em todo o mundo. Milhões de pessoas saíram do seu país de origem, por inúmeros motivos, ou foi pela fome, ou em busca de um novo emprego, ou de estudo, todos movidos por um único sentimento: a esperança de conseguir uma vida melhor.

E por fim o interpretante que nada mais é que o sentimento, a reação que as fotografias passam, elas permitem ao observador pensar e principalmente refletir. A maioria das pessoas está acostumada a se importar somente com o próprio umbigo, com as próprias vontades e desejos, poucas as vezes olha-se para o lado, vivendo isoladamente no próprio mundo de interesses. Ao observar qualquer uma destas fotografias é impossível não se colocar na realidade da pessoa que ali está com fome, com medo, com frio, com sede. É isto que as tornam tão especiais e únicas. As imagens são como uma máquina do tempo, que com um simples olhar podem imergir o observador em outra realidade e proporcionar sensações e sentimentos.

O papel da fotografia na vida das pessoas é exatamente este eternizar momentos, lembranças, emoções. Porém, estas imagens vão além,

Rev.Cad. Comun. Santa Maria, v.21, n.1, art 7, p.167 de 171, jan/abr.2017 
elas retratam uma realidade que não é muito comum, mas que em instantes passa a ser.

As conclusões, concernentes à análise das fotografias do projeto de Sebastião Salgado, não podem ser consideradas como finalizadas. Muitos outros estudiosos poderão continuar esta análise, compreende-se que o projeto "Êxodos" se configura como uma obra de arte da fotografia, e, diante disto, pode gerar sempre novas significações e possibilidades de atribuição de sentidos.

\section{CONCLUSÃO}

O mundo passa por constantes mudanças, tanto econômicas e políticas como tecnológicas. Esta mudança reflete significativamente no movimento migratório da população. Pessoas que buscam por uma vida melhor, por um último respiro de esperança. Percebe-se uma revolução na maneira de viver, produzir, comunicar, urbanizar e viajar, formando, assim, um só mundo.

O projeto "Êxodos" conta a história da humanidade em trânsito, em geral as pessoas retratadas em suas fotografias são migrantes, refugiados ou exilados. Elas estão fugindo da pobreza, da repressão ou das guerras. Durante seis anos, Sebastião Salgado passou por quarenta países, retratando fugitivos nas estradas, em campo de refugiados, ou ainda em favelas urbanas. Muitos desses atravessavam os piores momentos de suas vidas.

Salgado espera que a pessoa ao sair de suas exposições não seja a mesma no momento em que entrou. Ele comenta em uma de suas entrevistas que existe uma preocupação com isto, que os observadores reflitam sobre a situação social. De certa maneira, pode-se dizer que sua fotografia retrata a miséria, a fome e a exclusão. Suas lentes mostram a desigualdade existente no mundo. É realmente uma denúncia sobre a condição humana. Sobrinho (2013).

A semiótica, ciência geral de todos os signos, é uma das formas pelas quais se pode compreender e analisar o interior das mensagens e os significados que as fotografias estão aptas a produzir, pois penetram na construção estrutural da mensagem, auxiliando a interpretação. A semiótica foi possível pelos esforços de Peirce (2008), a partir das tricotomias e das classes dos signos. Compreende-se o signo como um elemento que 
representa outras coisas diferentes dele e que possibilita diversas interpretações.

Das cinco fotografias analisadas, foi possível compreender que o artista apresenta suas fotos de forma objetiva. Em cada uma de suas viagens, ele buscou trazer símbolos, signos e representações das coisas. Trata-se de uma denúncia da condição humana e do processo migratório que ocorreu no final do século XX, onde milhares de pessoas saíram dos seus países de origem em busca de uma vida melhor. Todas as fotografias têm aspectos em comum, formam assim uma única linguagem fotográfica, unidas pelo recurso preto e branco, que pôde ser analisado por meio da semiótica.

O papel deste Trabalho de Conclusão de Curso também contribui com os estudos da semiótica associada à comunicação e à produção de sentidos e significados.

\section{REFERÊNCIAS}

BARTHES, Roland. A câmara clara. Tradução: Júlio Castañon Guimarães. Rio de Janeiro: Nova Fronteira, 1984.

BRESSON, Henri Cartier. Aperture masters of photography. 1. ed. New York: GG BR, 2015 .

FOLTS, James; LOVELL, Ronald; ZWAHLEN, Fred. Manual de fotografia. São Paulo: Thomson, 2007.

HOFF, Tânia; GABRIELLI, Lourdes. Redação Publicitária. Rio de Janeiro: Campus, 2004.

KOSSOY, Boris: Fotografia \& história. São Paulo: Ateliê Editorial, 2009.

MCLUHAN, Marshall. Os meios de comunicação como extensões do homem. 9. ed. São Paulo: 1969.

PEIRCE, Charles Sanders. Semiótica. Tradução: J. Teixeira Coelho. São Paulo: Perspectiva,

2008.

Rev.Cad. Comun. Santa Maria, v.21, n.1, art 7, p.169 de 171, jan/abr.2017 
Semiótica e filosofia. Tradução: Octanny S. da Mora e Leônidas Hegenberg. São Paulo: Cultrix, 1972.

SALGADO, Sebastião. Da minha terra à terra. São Paulo: Schwarcz, 2013.

SANTAELLA, Lucia. Leitura de imagens. São Paulo: Melhoramentos, 2012.

. O que é semiótica. São Paulo: Brasiliense, 2005.

. Semiótica aplicada. São Paulo: Pioneira Thomson Learning, 2002.

Rev.Cad. Comun. Santa Maria, v.21, n.1, art 7, p.170 de 171, jan/abr.2017 


\section{Talita Savaris}

Graduação em Comunicação Social habilitação em Publicidade e Propaganda da UNOESC Joaçaba. Atua como publicitária no setor de Comunicação e Marketing da UNOESC Joaçaba.

E-mail: savaris.thalita@hotmail.com

\section{Silvia Spagnol Simi dos Santos}
Mestre em Ciências da Linguagem, possui Especialização em Comunicação e Marketing, Especialização em Novas Mídias, Rádio e TV, MBA em Estratégias de Marketing e graduação Publicidade e Propaganda. É Coordenadora e Professora do curso de Publicidade e Propaganda da UNOESC Joaçaba.
E-mail: silvia.simi@unoesc.edu.br

RECEBIDO EM: 29/02/16

ACEITO EM: 27/04/2016 